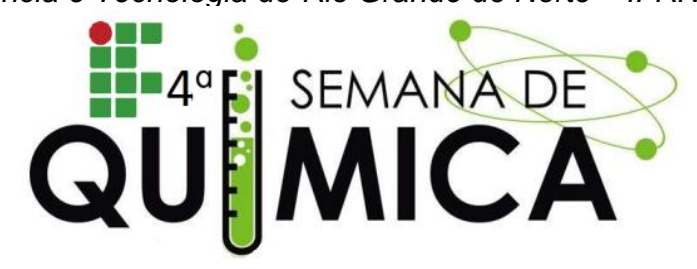

\title{
LARVICIDA E PESTICIDA A PARTIR DA ALOE VERA (BABOSA) PARA O COMBATE DO MOSQUITO AEDES AEGYPTI
}

\author{
Autores: SILVA, D. M. B. (IFRN), SILVA, I. B. A. (IFRN); SOUZA, D. S. (ORIENTADORA)
}

Palavras Chave: Aedes Aegypti, biolarvicida, Aloe vera.

\section{INTRODUÇÃO}

A dengue se tornou um grande problema de saúde pública, sendo responsável pelo maior número de hospitalizações no mundo, atinge principalmente os países de climas topicais em razão do clima quente e úmido, (Dias, et.al, 2010).

Muitas espécies vegetais existentes produzem substâncias que atuam como atraentes ou repelentes de outros organismos. São substâncias que possuem atividade biológica (SAITO, 2004).

A Aloe Vera é uma planta ornamental onde apresenta um grande poder de penetração tecidual, atuando em dores articulares como musculares. Também é considerado forte bactericida, cicatrizante entre outros (Neves e Nunes, 2010).

Devido inúmeras utilidades da babosa, objetivamos avaliar a ação repelente do óleo da Aloe vera (babosa), e verificar o pó da casca da mesma, como ação larvicida contra insetos, visando o mosquito aedes aegypti.

\section{METODOLOGIA}

Inicialmente foi feito uma seleção das folhas mais saudáveis da babosa, em seguida foram colhidas duas folhas, lavadas e recortadas em espessura de $5 \mathrm{~cm}$, com facas de corte. Posteriormente o gel foi exposto através da retirada da casca, onde passou por outra lavagem e em sequência foi triturado no liquidificador, deixado decantar por dez minutos, após esse tempo, obteve-se um líquido gelatinoso. As cascas, que foram retiradas da parte gelatinosa da babosa foram levadas a estufa e submetidas a uma temperatura de $100^{\circ} \mathrm{C}$ durante seis horas, por fim foram trituradas no moinho de facas, adquirindo assim um pó.

\section{Análise do gel como Larvicida}

As larvas foram capturadas utilizando a pipeta de Pasteur e em seguida distribuíramse 3 larvas em cada um dos 5 béquer $(100 \mathrm{~mL}$ ) contendo $30 \mathrm{~mL}$ de água corrente. Logo após, foi adicionado gotas do gel da babosa em cada amostra, o procedimento foi realizado em triplicata, e cronometrou-se um tempo de 10 minutos para cada teste.

Após o teste com o gel, adicionou-se $50 \mathrm{~mL}$ do pó da casca da babosa, no 5 ㅇ recipiente onde continha maior concentração do gel, e esperou-se por $10 \mathrm{~min}$.

\section{RESULTADOS E DISCUSSÕES}

Tabela 1. Análise do gel e da casca da babosa como larvicida, para o combate do mosquito Aedes Aegypti

\begin{tabular}{|c|c|c|c|c|}
\hline \multirow[t]{3}{*}{ AMOSTRA } & \multirow{2}{*}{\multicolumn{3}{|c|}{$\begin{array}{l}\text { GOTAS POR } \\
\text { TENTATIVAS }\end{array}$}} & \multirow[t]{3}{*}{ TEMPO (MIN) } \\
\hline & & & & \\
\hline & $1 \underline{a}$ & $2 \mathrm{a}$ & 3a & \\
\hline 1 & 5 & 10 & 15 & 10 \\
\hline 2 & 7 & 12 & 17 & 10 \\
\hline 3 & 9 & 14 & 19 & 10 \\
\hline 4 & 11 & 16 & 21 & 10 \\
\hline 5 & 13 & 18 & 23 & 10 \\
\hline
\end{tabular}

Como mostra a tabela 1 , na primeira amostra foi adicionado 5 gotas do gel da babosa, onde estavam as larvas, em sequência as gotas foram colocadas nos demais recipientes com uma variação de 2 gotas por béquer. 
Na segunda tentativa a quantidade do gel adicionado foi o dobro do primeiro, sendo que nos demais recipientes a variação continuou sendo a mesma, 2 gotas por béquer.

No ultimo teste a quantidade do gel foi o triplo do primeiro, 15 gotas foram adicionadas, e a variação nos outros recipientes permaneceu a mesma.

Todos os testes foram realizados em um tempo de 10 minutos, totalizando 30 minutos, sendo 10 minutos para cada tentativa.

Em todos os testes as larvas se mostraram resistentes a planta, aonde não conseguiu matar nenhuma delas.

Para a análise da casca da babosa, foi pesado na balança analítica $50 \mathrm{mg}$ do pó da casca e adicionado no último béquer que estava com maior concentração de gel, sendo cronometrado o mesmo tempo de espera, mas o resultado continuou sendo negativo, ou seja a babosa da forma tratada não apresentou atividade larvicida.

\section{CONCLUSÃO}

Diante do exposto anteriormente, podemos afirmar de forma preliminar que a casca e o gel da babosa, nos testes realizados, não apresentaram nenhuma atividade larvicida contra o mosquito Aedes Aegypti. Embora tenha muitas propriedades medicinais, nenhum dos componentes testados foi capaz de matar as larvas. A pesquisa terá continuidade com os testes enquanto repelente e ainda sua eficácia associada a outros óleos como larvicida.

\section{REFERÊNCIAS}

${ }^{1}$ DIAS, Larissa B. A. Ribeirão Preto, SP.

Disponível em:

http://revista.fmrp.usp.br/2010/vol43n2/Simp

6_Dengue.pdf/> acessado em, 20 de Julho de 2016

${ }^{2}$ SAITO, Maria. L. Embrapa, Meio Ambiente.

Jaguariúna. Disponível em:

https://www.agencia.cnptia.embrapa.br/recurs

os/Saito_plantasID-xWZZuffPN5.pdf/>

acessado em, 20 de Julho de 2016
${ }^{3}$ NEVES, Eduardo A. e NUNES, Jeanine M. S. estudo bibliográfico. Disponível em:

http://fisiobuzios.com.br/acao-do-aloe-verababosa-no-processo-inflamatorio-estudobibliografico/> acessado em, 21 de Julho de 2016. 